\title{
Penggunaan Bahan Organik dan Kombinasinya dalam Formulasi Biofungisida Berbahan Aktif Jamur Trichoderma pseudokoningii Rifai. untuk Menghambat Jamur Ganoderma boninense Pat. secara in vitro
}

\author{
Yetti Elfina*, Muhammad Ali, dan Rachmad Saputra \\ Fakultas Pertanian Universitas Riau, \\ Jalan Bina widya km 12,5 Simpang Baru Pekanbaru 28293
}

Diterima 11-12-2012Ｄisetujui 25-11-2013

\begin{abstract}
Trichoderma pseudokoningii has been applied as a biocontrol agent against fungal plant pathogen, such as Ganoderma boninense, the cause of stem rot disease on palm oil plants. To be more effectively applicable in the field, some experiments have been employed to formulate T. pseudokoningii in a biofungicide formulation amended with organic matter as its main nutrient resource, zealot as a carrier agent and cocoyam powder as a mixture agent. A research has been conducted to study the effect of various organic matters and their combinations in a biofungicide formulation of T. pseudokoningii on growth inhibition to G. boninense in-vitro and to obtain the best organic matters and their combinations in enhancing the growth of T. pseudokoningii and yet inhibiting G. boninense. The research has been conducted in the Laboratory of Plant Pathology, Agriculture Faculty, University of Riau from May to August 2012, using a completely randomized design consisting of 15 treatments (bagasse, rice husk, shrimp shell, dregs, and their combinations) and 3 replications. The data were statistically analyzed using analysis of variance, followed by Duncan's New Multiple Range Test (DNMRT). The results indicated that organic matters and their combinations in the biofungicide formulation significantly affected the antagonistic capacity of T. pseudokoningii in inhibiting the growth of $G$. boninense in vitro. Rice husk, bagases, bagasse+rice husks, and bagasse+dregs were the best organic matters in enhancing the growth of $T$. pseudokoningii and its capacity to inhibit G. boninense in-vitro. It can also be concluded that shrimp shell, bagasse+shrimp shell, rice husk+shrimp shell, shrimp shell+dregs and rice husk+shrimp shell+dregs totally inhibited the growth of T. pseudokoningii in the biofungicide formulation.
\end{abstract}

Keywords: biofungicide formulation, Ganoderma boninense, organic matters, Trichoderma pseudokoningii

\begin{abstract}
ABSTRAK
Jamur Trichoderma pseudokoningii Rifai. dapat digunakan untuk mengendalikan jamur Ganoderma boninense Pat, penyebab penyakit busuk pangkal batang pada kelapa sawit. Aplikasi T. pseudokoningii di lapangan umumnya masih dalam bentuk substrat dan kompos. Cara ini kurang tepat, sehingga agen hayati Trichoderma sp tersebut perlu diformulasi. Formulasi biofungisida terdiri dari bahan aktif, bahan makanan (sumber nutrisi), bahan pembawa, dan bahan pencampur. Bahan organik seperti ampas tebu, sekam padi kulit udang, dan dregs dapat digunakan sebagai sumber nutrisi bagi $T$. pseudokoningii. Bahan pembawa yang digunakan yaitu zeolit. Penelitian ini bertujuan 1) untuk mengetahui pengaruh penggunaan beberapa bahan organik dan kombinasinya dalam formulasi biofungisida yang berbahan aktif T. pseudokoningii dalam menghambat pertumbuhan $G$. boninense; 2) untuk mendapatkan bahan organik dan kombinasinya sebagai sumber nutrisi dalam formulasi biofungisida yang paling mendukung pertumbuhan dan daya hambat T. pseudokoningii terhadap jamur G. boninense secara in vitro. Penelitian ini telah dilaksanakan di Laboratorium Penyakit Tumbuhan, Fakultas Pertanian,
\end{abstract}

*Telp: +6281378467728

Email:elfina68@yahoo.com 
Universitas Riau selama 4 bulan dari bulan Mei hingga Agustus 2012. Penelitian ini dilaksanakan dengan menggunakan Rancangan Acak Lengkap yang terdiri dari 15 perlakuan (ampas tebu, sekam padi, kulit udang, dregs dan kombinasinya) dan 3 ulangan. Data yang diperoleh dari pengamatan dianalisis secara statistik dengan menggunakan sidik ragam, dilanjutkan dengan Duncan'sNewMultipleRangeTest(DNMRT). Hasil penelitian menunjukkan bahwa bahan organik dan kombinasinya dalam formulasi biofungisida berpengaruh terhadap daya hambat jamur T. pseudokoningii terhadap jamur G. boninense secara in vitro. Sekam padi, ampas tebu, ampas tebu+sekam padi dan ampas tebu+dregs memiliki kemampuan yang baik dalam mendukung pertumbuhan dan daya hambat jamur T. pseudokoningii terhadap G. boninense dibandingkan dengan bahan organik lainnya. Penggunaan kulit udang, ampas tebu+kulit udang, sekam padi+kulit udang, kulit udang+dregs dan sekam padi+kulit udang+dregs dalam formulasi biofungisida menyebabkan pertumbuhan jamur T. pseudokoningii terhambat.

Kata Kunci: Trichoderma pseudokoningii, bahan organik, fungisida, formula, Ganoderma boninense

\section{PENDAHULUAN}

Pengendalian jamur patogen tanaman masih banyak dilakukan petani melalui cara kimiawi dengan penggunaan fungisida sintetik. Hal tersebut dikarenakan penggunaan fungisida sintetik menunjukkan pengaruh yang lebih cepat dalam melindungi tanaman dari serangan patogen, mudah didapat serta aplikasinya yang mudah dan praktis. Ketergantungan akan penggunaan fungisida sintetis ini tanpa disadari banyak menimbulkan dampak negatif. Beberapa dampak negatif yang muncul akibat penggunaannya ini antara lain adalah munculnya ras-ras baru dari patogen, terbunuhnya musuh alami dan jasad non-target. Penggunaan fungisida sintetis juga akan berdampak buruk bagi kelestarian dan kualitas ekosistem karena residu yang ditinggalkannya, sehingga diperlukan alternatif pengendalian penyakit yang dapat mengurangi penggunaan fungisida sintetik yang berdampak buruk tersebut. Salah satunya adalah dengan pengendalian hayati menggunakan jamur antagonis yang dapat menekan pertumbuhan jamur patogen tanaman. Jamur antagonis Trichoderma sp. dan Gliocladium sp. dilaporkan mampu menghambat patogen lodoh (Baker \& Cook 1974)

Jamur Trichoderma sp. adalah salah satu agen hayati yang telah banyak diuji kemampuan antagonisnya pada beberapa jamur patogen dan menunjukkan hasil yang baik. Penggunaan jamur Trichoderma sp. untuk pengendalian penyakit di lapangan masih dalam bentuk starter dan kompos, dan masih sedikit yang dalam bentuk formulasi. Penggunaan dalam bentuk kompos maupun starter oleh petani mempunyai beberapa kendala, antara lain memerlukan ruang yang relatif luas dalam penyimpanannya, sulit dalam penyiapan dan perbanyakan isolat jamur Trichoderma sp.,serta kurang stabilnya pertumbuhan dan kemampuan jamur trichoderma setelah diaplikasikan di lapangan. Selain itu, jamur Trichoderma sp. yang terdapat di dalam bentuk starter dan kompos ini tidak stabil karena tidak adanya bahan tambahan yang dapat menjaga kestabilan jamur Trichoderma sp. Oleh karenanya, perlu suatu teknik pengemasan agen hayati dalam suatu bentuk formulasi seperti pada fungisida sintetik sehingga mudah diaplikasikan oleh petani.

Menurut Weller dan Cook (1983), untuk menstabilkan efektivitas agensia hayati seperti Trichoderma sp. harus diformulasikan. Formulasi bertujuan untuk menjaga kestabilan kemampuan agen hayati sehingga dapat disimpan, mudah dalam pengangkutan dan penerapannya serta mudah didapat oleh petani. Purwantisari et al. (2008) menyatakan di dalam suatu formulasi harus terdapat bahan aktif, bahan makanan, bahan pembawa, dan bahan pencampur.

Selama pertumbuhannya Trichoderma sp. memerlukan bahan-bahan makanan dalam senyawa organik sebagai sumber karbon dan energi. Berdasarkan hasil penelitian Winarsih dan Syafrudin (2001), bahwa sekam padi dapat memacu pertumbuhan $T$. viride dan penggunaannya dapat menurunkan persentase serangan Fusarium oxysporum pada bibit cabai. Bahan organik lain yang juga dapat dimanfaatkan sebagai medium pertumbuhan diantaranya adalah dregs (limbah pabrik kertas), ampas tebu dan kulit udang yang juga memiliki senyawa karbon di dalamnya.

Sekam padi mengandung protein, lemak, serat, dan karbohidrat (Suharno 1979) sedangkan ampas tebu mengandung serat, ligno-cellulose, dan gula (Husin 2007). Kulit udang mengandung protein dan kalsium karbonat dan dregs mengandung unsur-unsur nitrogen, fosfor, 
kalsium, dan magnesium (Elfina et al. 2007). Kandungan dari setiap bahan-bahan tersebut di atas merupakan sumber nutrisi yang dapat dimanfaatkan jamur T. pseudokoningii untuk menunjang pertumbuhan dan kemampuan antagonisnya.

Elfina et al. (2010) melaporkan bahwa $T$. pseudokoningii Rifai yang diisolasi dari rizosfir tanaman kelapa sawit di Riau dapat memperlambat munculnya serangan penyakit yang disebabkan $G$. boninense Pat. di pembibitan awal kelapa sawit. Berdasarkan hasil penelitian Susanto et al. (2005), jamur Trichoderma sp. dalam bentuk starter dengan dosis $10 \mathrm{~g} /$ polibag dan kerapatan konidia 4 × $10^{6}$ konidia/mL juga dapat mencegah munculnya penyakit busuk pangkal batang pada bibit sawit. Kharisma (2011) menyimpulkan pula bahwa jamur T. pseudokoninggi yang diaplikasikan dalam beberapa konsentrasi dregs yang berbeda (20-100\%) maupun tanpa dregs dapat menghambat perkembangan jamur G. boninense secara in-vitro sebesar 8,74-13,69\%. Jamur Trichoderma sp. yang diformulasikan dalam bahan-bahan tersebut diharapkan sebagai agen pengendali hayati terhadap jamur G. boninense Pat. yang menyebabkan penyakit busuk pangkal batang pada tanaman kelapa sawit. Berdasarkan hal tersebut, maka tujuan penelitian adalah 1) untuk mengetahui pengaruh penggunaan beberapa bahan organik dan kombinasinya dalam formulasi biofungisida yang berbahan aktif T. pseudokoningii dalam menghambat pertumbuhan dan perkembangan $G$. boninense; 2) untuk mendapatkan bahan organik dan kombinasinya sebagai sumber nutrisi dalam formulasi biofungisida yang paling mendukung pertumbuhan dan daya hambat $T$. pseudokoningii terhadap jamur G. boninense secara in vitro.

\section{BAHAN DAN METODE}

Penelitian ini dilaksanakan di Laboratorium Penyakit Tumbuhan Fakultas Pertanian Universitas Riau, Simpang Baru Panam Pekanbaru. Penelitian berlangsung selama 4 bulan dari bulan Mei sampai Agustus 2012. Bahan-bahan yang digunakan adalah beberapa jenis bahan organik (sekam padi, ampas tebu, limbah udang, dan dregs), isolat T. pseudokoningii Rifai dan isolat $G$. boninense (koleksi Laboratorium Penyakit Tumbuhan Fakultas Pertanian), zeolit, medium Potato Dextrosa Agar (PDA) dan medium aktivasi jamur antagonis, plastic wrap, alkohol 70\%, akuades steril, aluminium foil, plastik kaca (polyethylen), kapas, dan kertas label.

Penelitian ini dilaksanakan secara eksperimen dengan mengunakan Rancangan Acak Lengkap yang terdiri dari 15 perlakuan dan 3 ulangan, sehingga diperoleh 45 unit percobaan. Perlakuan yang diuji adalah beberapa bahan organik dan kombinasinya (F) yang dicampurkan dengan zeolit dengan perbandingan 2:1 sebagai berikut: $\mathrm{F}_{1}=$ ampas tebu, $\mathrm{F}_{2}=$ sekam padi, $\mathrm{F}_{3}=$ kulit udang, $\mathrm{F}_{4}=$ dregs, $\mathrm{F}_{5}=$ ampas tebu+sekam padi, $\mathrm{F}_{6}=$ ampas tebu+kulit udang, $\mathrm{F}_{7}=$ ampas tebu+dregs, $\mathrm{F}_{8}=$ sekam padi+kulit udang, $\mathrm{F}_{9}=$ sekam padi+dregs, $\mathrm{F}_{10}=$ kulit udang + dregs, $\mathrm{F}_{11}=$ ampas tebu+sekam padi+kulit udang, $\mathrm{F}_{12}=$ ampas tebu+sekam padi+dregs, $\mathrm{F}_{13}=$ ampas tebu+kulit udang+dregs, $\mathrm{F}_{14}=$ sekam padi+kulit udang+dregs, $\mathrm{F}_{15}=$ ampas tebu+sekam padi+kulit udang+dregs. Data yang diperoleh dari pengamatan dianalisis secara statistik dengan menggunakan sidik ragam dan dilanjutkan dengan uji Duncan's New Multiple Range Test (DNMRT) pada taraf $5 \%$.

Ampas tebu, limbah udang, sekam padi, dan dregs sebanyak $3 \mathrm{~kg}$ masing-masing dikeringanginkan selama 2 minggu sehingga mudah untuk dihaluskan. Bahan-bahan tersebut dihaluskan dengan menggunakan blender. Bahanbahan yang telah hancur disaring dengan menggunakan saringan untuk mendapatkan tepungnya. Hasilnya kemudian disimpan dalam plastik polyethylen secara terpisah. Total tepung yang dihasilkan sebanyak $1,5 \mathrm{Kg}$ dari $3 \mathrm{Kg}$ bahan segar untuk masing-masing bahan organik. Sedangkan jumlah tepung dari ampas tebu, limbah udang, sekam padi dan dregs untuk masing-masingnya yang digunakan adalah sebanyak $1,125 \mathrm{~g}, 100 \mathrm{~g}$ dari masingmasing bahan organik dan $50 \mathrm{~g}$ zeolit dimasukkan ke dalam kantong plastik polyethylen. Bagian ujung plastik dipasang cincin pipa paralon dan ditutup dengan kapas lalu dilapisi aluminium foil dan plastic wrap. Bahan-bahan tersebut disterilkan dalam autoclave pada tekanan $1 \mathrm{~atm}$ dan suhu $121^{\circ} \mathrm{C}$ selama 20 menit. Biomassa konidia jamur T. pseudokoningii dengan kerapatan 106 konidia/mL dimasukkan ke dalam bahan dalam kantong plastik polyethylen, kemudian diaduk sampai tercampur merata. Formulasi ini siap digunakan untuk pengujian. 
Pengamatan. Kecepatan Pertumbuhan Koloni Jamur T. pseudokoningii dalam Formulasi Biofungisida (mm/ hari). Kecepatan pertumbuhan koloni T. pseudokoningii yang terdapat dalam formulasi biofungisia didapatkan dengan mengukur diameter koloni jamur T. psedokoningii dari formulasi biofungisida yang ditumbuhkan pada medium PDA, diameter koloni jamur diukur dengan menggunakan kertas milimeter. Pengukuran dilakukan tiap hari sampai cawan petri penuh dan dilakukan pada dua tempat yang tetap pada cawan petri bagian belakang, kemudian ditentukan rata-rata kecepatan pertumbuhan koloni per hari.

Diameter Koloni Jamur T. pseudokoningii pada Formulasi Biofungisida (mm). Pengamatan dilakukan setiap hari terhadap koloni jamur T. pseudokoningii yang terdapat dalam formulasi biofungida yang ditumbuh pada cawan petri untuk tiap unit percobaan. Pengukuran diameter koloni dilakukan ketika koloni jamur yang tumbuh pada medium PDA yang telah diinokulasikan dengan formulasi biofungisida sesuai perlakuan telah memenuhi cawan petri. Alat yang digunakan dalam pengukuran adalah kertas milimeter. Cara penghitungan diameter koloni dilakukan dengan membuat garis vertikal dan horizontal yang berpotongan tepat pada titik tengah koloni jamur pada cawan petri. Garis dibuat di bagian bawah cawan petri yang berfungsi untuk mempermudah perhitungan diameter koloni. Cara pengukuran pada cawan petri berdasarkan rumus:

$$
\mathrm{D}=\frac{\mathrm{d}_{1}+\mathrm{d}_{2}}{2}
$$

Keterangan :

$\mathrm{D}$ = diameter jamur T. pseudokoningii

$\mathrm{d}_{1}=$ diameter vertikal koloni jamur T. pseudokoningii

$\mathrm{d}_{2}=$ diameter horizontal koloni jamur T. pseudokoningii

Uji Penghambatan Pertumbuhan Jamur Patogen $G$ Boninense pada Formulasi Biofungisida. Kemampuan penghambatan terhadap pertumbuhan jamur $G$. boninense pada masing-masing formulasi biofungisida dihitung sampai ada jamur T. pseudokoningii pada setiap perlakuan yang telah tumbuh hingga ke bagian pinggir koloni jamur G. boninense setelah ditumbuhkan pada medium PDA. Persentase penghambatan dihitung dengan rumus:

$$
\mathrm{P}=\frac{\mathrm{r}_{1}-\mathrm{r}_{2}}{\mathrm{r}_{1}} \times 100 \%
$$

Keterangan :

$\mathrm{P}=$ kemampuan penghambatan $(\%)$

r1 = jari-jari koloni patogen yang menjauhi formulasi biofungisida

r2 = jari-jari koloni patogen yang mendekati formulasi biofungisida

Jumlah Spora dalam Formulasi Biofungisida (CFU/ mL). Jumlah spora dalam formulasi biofungisida dihitung dengan metode hitungan cawan (plate count). Jumlah koloni dalam formulasi biofungisida dapat dihitung dengan metode hitungan cawan adalah sebagai berikut:

Jumlah spora $(\mathrm{CFU} / \mathrm{mL})=$ Jumlah koloni per cawan $\mathrm{X}$ 1

faktor pengeceran

Pengukuran pH formulasi biofungisida. Pengukuran $\mathrm{pH}$ pada formulasi biofungisida dilakukan dengan mengambil sampel formulasi biofungisida (sesuai dengan perlakuan) sebanyak $5 \mathrm{~g}$ yang dilarutkan ke dalam $10 \mathrm{~mL}$ akuades dan diukur menggunakan $\mathrm{pH}$ meter.

\section{HASIL DAN PEMBAHASAN \\ Kecepatan Pertumbuhan Koloni Jamur T. pseudokoningii dalam Formulasi Biofungisida di} Medium PDA. Penggunaan beberapa bahan organik dan kombinasinya dalam formulasi biofungisida memberikan pengaruh yang nyata terhadap kecepatan pertumbuhan koloni jamur T. pseudokoningii dalam formulasi biofungisida yang ditumbuhkan kembali di media PDA setelah dianalisis ragam. Hasil uji lanjut DNMRT pada taraf 5\% dapat dilihat pada Tabel. 1 .

Kecepatan pertumbuhan koloni jamur $T$. pseudokoningii pada Tabel 1 dengan formulasi biofungisida yang menggunakan bahan organik ampas tebu $\left(\mathrm{F}_{1}\right)$, sekam padi $\left(\mathrm{F}_{2}\right)$, ampas tebu + dregs $\left(\mathrm{F}_{7}\right)$, ampas tebu+sekam padi $\left(\mathrm{F}_{5}\right)$ dan ampas tebu+sekam padi+dregs $\left(F_{12}\right)$ menunjukkan hasil yang berbeda tidak nyata sesamanya, namun berbeda nyata dengan formulasi biofungisida yang mengandung bahan organik dan kombinasi lainnya dengan kecepatan pertumbuhan yang lebih tinggi (52,78-49,28 mm/hari). Perbedaan kecepatan pertumbuhan koloni jamur T. pseudokoningii pada beberapa bahan organik dan kombinasinya tersebut diduga karena adanya perbedaan kandungan senyawa masingmasing bahan organik yang berfungsi sebagai sumber 
nutrisi bagi jamur T. pseudokoningii. Berdasarkan hasil penelitian Elfina et al. (2001), jamur antagonis sangat membutuhkan nutrisi essensial dalam pertumbuhannya. Adnan (1991) dalam Trizelia (2013) menegaskan pula bahwa kecepatan pertumbuhan koloni jamur dipengaruhi antara lain oleh media tumbuhnya, dimana pada media yang berbeda maka kecepatan tumbuhnya juga berbeda.

Nutrisi yang diduga berperan besar dalam mempercepat pertumbuhan jamur pada formulasi biofungisida yang mengandung ampas tebu $\left(\mathrm{F}_{1}\right)$, sekam padi $\left(\mathrm{F}_{2}\right)$, ampas tebu+dregs $\left(\mathrm{F}_{7}\right)$, ampas tebu+sekam padi $\left(\mathrm{F}_{5}\right)$ dan ampas tebu+sekam padi+dregs $\left(\mathrm{F}_{12}\right)$ adalah adanya kandungan serat dan karbohidrat yang banyak terkandung di dalam ampas tebu dan sekam padi. Husin (2007) mengemukakan bahwa ampas tebu mengandung serat sebesar $47,7 \%$. Sekam padi mengandung serat dan karbohidrat yang masing-masingnya sebesar 35,68\% dan $33,71 \%$ (Suharno,1979), sedangkan di dalam setiap $1 \mathrm{Kg}$ dregs terdapat kandungan N-total $40 \mathrm{mg}$, P-total $37 \mathrm{mg}$, $\mathrm{K} 4 \mathrm{mg}$, Ca $32 \mathrm{mg}, \mathrm{Mg} 48$ mg, Fe 52,12 mg, Zn 20,14 mg, Cu $50 \mathrm{mg}, 20 \mathrm{mg}$, Mo 3,14 mg, dan Al 1,9 mg (Elfina et al. 2007). Unsur-unsur yang terkandung di dalam dregs ini dapat lebih memperkaya formulasi biofungisida tersebut (ampas tebu dan sekam padi) sehingga lebih dapat merangsang kecepatan pertumbuhan koloni jamur T. pseudokoningii .
Data pada Tabel 1 juga menunjukkan kecepatan pertumbuhan jamur T. pseudokoningii dalam formulasi biofungisida yang mengandung beberapa komposisi bahan organik seperti: ampas tebu+sekam padi+kulit udang $\left(\mathrm{F}_{11}\right)$, ampas tebu+kulit udang+dregs $\left(\mathrm{F}_{13}\right)$, ampas tebu+sekam padi+kulit udang+dregs $\left(\mathrm{F}_{15}\right)$, sekam padi+dregs $\left(\mathrm{F}_{9}\right)$ dan dregs $\left(\mathrm{F}_{4}\right)$ setelah ditumbuhkan kembali di media PDA adalah lebih rendah (41,28-22,33 mm/hari). Penggunaan bahan organik kulit udang $\left(\mathrm{F}_{3}\right)$, ampas tebu+kulit udang $\left(\mathrm{F}_{6}\right)$, sekam padi+kulit udang $\left(\mathrm{F}_{8}\right)$, kulit udang+dregs $\left(\mathrm{F}_{10}\right)$ dan sekam padi+kulit udang+dregs $\left(\mathrm{F}_{14}\right)$ juga menyebabkan kecepatan pertumbuhan jamur T. pseudokoningii bernilai $0 \mathrm{~mm} / \mathrm{hari}$ yang berarti jamur T. pseudokoninggi tidak dapat tumbuh dan berkembang sama sekali. Rendahnya kecepatan pertumbuhan dan bahkan tidak tumbuhnya jamur $T$. pseudokoningii pada formulasi yang mengandung bahan organik dan kombinasinya ini diduga karena adanya senyawa tertentu yang mampu menghambat pertumbuhan dan perkembangan dari jamur T. pseudokoningii, yakni kandungan khitin pada kulit udang serta adanya kandungan logam berat pada dregs. Kulit udang mengandung khitin yang berkisar antara 18,70-32,20\%, sedangkan menurut Elfina et al. (2007) di dalam dregs terkandung logam berat seperti $\mathrm{Pb}$ dan $\mathrm{Cd}$. Derajat keasaman $(\mathrm{pH})$ dari formulasi yang mengandung

Tabel 1 Rerata kecepatan pertumbuhan koloni jamur T. pseudokoningii pada formulasi biofungisida yang mengandung bahan organik dan kombinasinya setelah ditumbuhkan kembali ke medium PDA (mm/hari)

\begin{tabular}{|c|c|}
\hline Perlakuan & $\begin{array}{c}\text { Rerata kecepatan pertumbuhan koloni jamur } \\
\text { T. pseudokoningii (mm/hari) }\end{array}$ \\
\hline Ampas Tebu $\left(\mathrm{F}_{1}\right)$ & $52,78 \mathrm{a}$ \\
\hline Sekam Padi $\left(\mathrm{F}_{2}\right)$ & $51,22 \mathrm{a}$ \\
\hline Ampas Tebu+Dregs $\left(\mathrm{F}_{7}\right)$ & 50,89 a \\
\hline Ampas Tebu+Sekam Padi $\left(\mathrm{F}_{5}\right)$ & $50,78 \mathrm{a}$ \\
\hline Ampas Tebu+Sekam Padi+Dregs $\left(\mathrm{F}_{12}\right)$ & $49,28 \mathrm{a}$ \\
\hline Ampas Tebu+Sekam Padi+Kulit Udang $\left(\mathrm{F}_{11}\right)$ & $41,28 \mathrm{~b}$ \\
\hline Ampas Tebu+Kulit Udang+Dregs $\left(\mathrm{F}_{13}\right)$ & $40,17 \mathrm{~b}$ \\
\hline Ampas Tebu+Sekam Padi+Kulit Udang+Dregs $\left(\mathrm{F}_{15}\right)$ & $30,39 \mathrm{c}$ \\
\hline Sekam padi+Dregs $\left(\mathrm{F}_{9}\right)$ & $27,89 \mathrm{c}$ \\
\hline Dregs $\left(\mathrm{F}_{4}\right)$ & $22,33 \mathrm{~d}$ \\
\hline Kulit Udang $\left(\mathrm{F}_{3}\right)$ & $00,00 \mathrm{e}$ \\
\hline Ampas Tebu+Kulit Udang $\left(\mathrm{F}_{6}\right)$ & $00,00 \mathrm{e}$ \\
\hline Sekam Padi+Kulit Udang $\left(\mathrm{F}_{8}\right)$ & $00,00 \mathrm{e}$ \\
\hline Kulit Udang+Dregs $\left(\mathrm{F}_{10}\right)$ & $00,00 \mathrm{e}$ \\
\hline Sekam Padi+Kulit Udang+Dregs $\left(\mathrm{F}_{14}\right)$ & $00,00 \mathrm{e}$ \\
\hline
\end{tabular}

Angka-angka yang diikuti oleh huruf kecil yang tidak sama adalah berbeda nyata menurut uji DNMRT pada taraf 5\% setelah data ditransformasi ke dalam $\operatorname{sine}^{-1} \sqrt{F}$ 
Tabel 2 Rerata diameter koloni jamur T. pseudokoningii pada formulasi biofungisida yang mengandung bahan organik dan kombinasinya setelah ditumbuhkan kembali di Medium PDA (mm)

\begin{tabular}{lc}
\hline \multicolumn{1}{c}{ Perlakuan } & $\begin{array}{c}\text { Rerata diameter koloni jamur T. pseudokoningii } \\
(\mathrm{mm})\end{array}$ \\
\hline Sekam Padi $\left(\mathrm{F}_{2}\right)$ & $90,00 \mathrm{a}$ \\
Ampas Tebu+Dregs $\left(\mathrm{F}_{7}\right)$ & $89,66 \mathrm{a}$ \\
Ampas Tebu $\left(\mathrm{F}_{1}\right)$ & $89,33 \mathrm{a}$ \\
Ampas Tebu+Sekam Padi $\left(\mathrm{F}_{5}\right)$ & $89,00 \mathrm{a}$ \\
Ampas Tebu+Sekam Padi+Kulit Udang $\left(\mathrm{F}_{11}\right)$ & $88,83 \mathrm{a}$ \\
Ampas Tebu+Sekam Padi+Dregs $\left(\mathrm{F}_{12}\right)$ & $87,83 \mathrm{a}$ \\
Ampas Tebu+Kulit Udang+Dregs $\left(\mathrm{F}_{13}\right)$ & $76,50 \mathrm{~b}$ \\
Ampas Tebu+Sekam Padi+Kulit Udang+Dregs $\left(\mathrm{F}_{15}\right)$ & $59,17 \mathrm{c}$ \\
Sekam padi+Dregs $\left(\mathrm{F}_{9}\right)$ & $45,67 \mathrm{~d}$ \\
Dregs $\left(\mathrm{F}_{4}\right)$ & $44,00 \mathrm{~d}$ \\
Kulit Udang $\left(\mathrm{F}_{3}\right)$ & $00,00 \mathrm{e}$ \\
Ampas Tebu+Kulit Udang $\left(\mathrm{F}_{6}\right)$ & $00,00 \mathrm{e}$ \\
Sekam Padi+Kulit Udang $\left(\mathrm{F}_{8}\right)$ & $00,00 \mathrm{e}$ \\
Kulit Udang+Dregs $\left(\mathrm{F}_{10}\right)$ & $00,00 \mathrm{e}$ \\
Sekam Padi+Kulit Udang+Dregs $\left(\mathrm{F}_{14}\right)$ & $00,00 \mathrm{e}$ \\
\hline
\end{tabular}

bahan organik dan kombinasinya juga dapat memberikan pengaruh terhadap kecepatan pertumbuhan jamur $T$. pseudokoningii. Nilai $\mathrm{pH}$ dari bahan organik ampas tebu $\left(\mathrm{F}_{1}\right)$, sekam padi $\left(\mathrm{F}_{2}\right)$, ampas tebu+sekam padi $\left(\mathrm{F}_{5}\right)$ dan ampas tebu+dregs $\left(\mathrm{F}_{7}\right)$ masing-masingnya adalah 4,07; 6,63; 5,48 dan 7,52 diduga memberi pengaruh baik terhadap kecepatan pertumbuhan jamur T. pseudokoningii dibandingkan komposisi dengan formulasi bahan organik lainnya yang memiliki nilai $\mathrm{pH}>8$. Menurut Gendjar et al. (1999), bahwa secara umum pertumbuhan jamur dipengaruhi oleh substrat, kadar air, $\mathrm{pH}$ substrat, dan senyawa kimia di lingkungannya. Hal ini juga ditegaskan oleh Budiyanto (2010) yang menyatakan bahwa pH berpengaruh terhadap pertumbuhan mikroorganisme. Cook dan Baker (1989) pula bahwa aktivitas jamur-jamur antagonis seperti Trichoderma sp. hanya terpacu pada kondisi asam. Samuels et al. (2010) dalam Uruilal et al. (2012), menambahkan bahwa pH optimum untuk pertumbuhan Trichoderma sp. berkisar 3-7. Elfina dan Rianti (2004) juga mengemukakan bahwa perkembangan populasi propagul Trichoderma sp. pada kompos tandan kosong sawit pada $\mathrm{pH}$ di atas 8 dapat terhambat.

Diameter Koloni Jamur T. pseudokoningii pada Formulasi Biofungisida di Medium PDA (mm). Penggunaan beberapa bahan organik dan kombinasinya dalam formulasi biofungisida memberikan pengaruh yang nyata terhadap diameter jamur T. pseudokoningii dalam formulsi biofungisida yang ditumbuhkan kembali di media PDA setelah dianalisis ragam. Hasil uji lanjut DNMRT pada taraf 5\% dapat dilihat pada Tabel. 2 .

Diameter koloni jamur T. pseudokoningii pada Tabel 2 memperlihatkan bahwa dengan penggunaan bahan organik: $F_{2}, F_{7}, F_{1}, F_{5}, F_{11}$, dan $F_{12}$ dalam formulasi biofungisida berbeda tidak nyata sesamanya, namun berbedanya nyata pada formulasi biofungisida yang mengandung komposisi bahan organik yang lainnya dan menunjukkan diameter yang paling besar yakni masingmasingnya sebesar 90,00; 89,66; 89,33; 89,00; 88,83 dan $87,83 \mathrm{~mm}$. Perbedaan diameter ini dapat terjadi karena kecepatan pertumbuhan dari koloni jamur T. pseudokoningii pada formulasi biofungisida yang mengandung masing-masing bahan organik dan kombinasinya juga berbeda (Tabel 1). Tersedianya nutrisi yang baik pada masing-masing bahan organik tersebut dapat lebih memicu pertumbuhan jamur yang tampak pada diameter koloni jamur T. pseudokoningii (Gambar 1).

Gambar 1 menunjukkan perbedaan diameter koloni jamur T. pseudokoningii yang dikarenakan perbedaan sumber nutrisi yang terkandung di dalam setiap formulasi biofungisida yang mengandung bahan organik dan kombinasinya. Wahyudi dan Suwahyono (1997) melaporkan bahwa kandungan serat dan karbohidrat yang cukup tinggi dalam suatu bahan dapat menjadi sumber nutrisi dan karbon yang potensial untuk pertumbuhan 
jamur Trichoderma spp. Senyawa-senyawa tersebut secara umum banyak terkandung di dalam sekam padi dan ampas tebu.

Berdasarkan hasil penelitian Griffin (1981) disimpulkan bahwa jamur antagonis sangat membutuhkan nutrisi esensial yang meliputi Karbon, Hidrogen, Oksigen, Fosfor, Nitrogen, Sulfur, dan Kalsium untuk pertumbuhannya. Carlile dan Watkinson (1995) dalam. Uruilal et al. (2012) juga mengemukakan bahwa fungsi utama nutrisi adalah sebagai sumber energi, bahan pembentuk sel dan aseptor elektron di dalam aksi untuk menghasilkan energi untuk pertumbuhan jamur $T$. pseudokoningii.

Daya Hambat Jamur T. pseudokoningii terhadap Pertumbuhan Jamur G. boninense pada Formulasi biofungisida di Medium PDA (\%). Penggunaan beberapa bahan organik dan kombinasinya dalam formulasi biofungisida memberikan pengaruh yang nyata terhadap daya hambat jamur T. pseudokoningii dalam formulasi biofungisida yang ditumbuhkan kembali di media PDA terhadap pertumbuhan jamur G. boninense sebagai jamur patogen uji setelah dianalisis ragam. Hasil uji lanjut DNMRT pada taraf 5\% dapat dilihat pada Tabel 3.

Daya hambat pertumbuhan jamur G. boninense oleh jamur T. pseudokoningii dalam formulasi biofungisida yang mengandung bahan organik sekam padi $\left(\mathrm{F}_{2}\right)$, ampas tebu+sekam padi $\left(\mathrm{F}_{5}\right)$,- ampas tebu $\left(\mathrm{F}_{1}\right)$ dan ampas tebu+dregs $\left(\mathrm{F}_{7}\right)$ berbeda nyata dibandingkan dengan formulasi biofungisida yang mengandung bahan organik yang lainnya, namun berbeda tidak nyata antar sesamanya (Tabel 3). Perbedaan komposisi senyawa di dalam bahan organik dapat menyebabkan perbedaan jumlah nutrisi yang tersedia bagi jamur $T$. pseudokoningii yang dapat dimanfaatkan jamur T. pseudokoningii untuk perkembangan dan daya hambatnya terhadap jamur G. boninense. Sekam padi dan ampas tebu mengandung serat dan karbohidrat yang lebih tinggi dan baik untuk menunjang pertumbuhan jamur T. pseudokoningii dibandingkan bahan organik lainnya. Suharno (1979) dalam Sugiarti dan Widyatama (2009) menyatakan bahwa sekam padi mengandung serat sebanyak 35,68\% dan karbohidrat sebesar $33,77 \%$, sedangkan ampas tebu hanya mengandung serat sebesar 47,7\% (Husin 2007).

Ketersediaan nutrisi yang lebih baik di dalam formulasi biofungisida yang mengandung bahan organik sekam padi dan ampas tebu menyebabkan jamur T. pseudokoningii dapat tumbuh lebih baik dimana diameter dan kecepatan tumbuhnya lebih tinggi dibandingkan dengan jamur G. boninense, sehingga lebih mampu dan cepat dalam memanfaatkan ruang dan nutrisi dibandingkan

Tabel 3 Rerata daya hambat jamur T. pseudokoningii terhadap pertumbuhan jamur G. boninense pada formulasi biofungisida yang mengandung bahan organik dan kombinasinya setelah ditumbuhkan kembali di medium PDA (\%)

Perlakuan
Rerata Daya Hambat Pertumbuhan Jamur

G. boninense (\%)

\begin{tabular}{ll}
\hline Sekam Padi $\left(\mathrm{F}_{2}\right)$ & $80,83 \mathrm{a}$ \\
Ampas Tebu+Sekam Padi $\left(\mathrm{F}_{5}\right)$ & $78,14 \mathrm{a}$ \\
Ampas Tebu $\left(\mathrm{F}_{1}\right)$ & $77,99 \mathrm{a}$ \\
Ampas Tebu+Dregs $\left(\mathrm{F}_{7}\right)$ & $74,17 \mathrm{a}$ \\
Ampas Tebu+Sekam Padi+Kulit Udang+Dregs $\left(\mathrm{F}_{15}\right)$ & $60,83 \mathrm{~b}$ \\
Ampas Tebu+Sekam Padi+Dregs $\left(\mathrm{F}_{12}\right)$ & $58,89 \mathrm{bc}$ \\
Ampas Tebu+Sekam Padi+Kulit Udang $\left(\mathrm{F}_{11}\right)$ & $57,63 \mathrm{bc}$ \\
Ampas Tebu+Kulit Udang+Dregs $\left(\mathrm{F}_{13}\right)$ & $51,37 \mathrm{~cd}$ \\
Sekam padi+Dregs $\left(\mathrm{F}_{9}\right)$ & $51,28 \mathrm{~cd}$ \\
Dregs $\left(\mathrm{F}_{4}\right)$ & $46,89 \mathrm{~d}$ \\
Kulit Udang $\left(\mathrm{F}_{3}\right)$ & $00,00 \mathrm{e}$ \\
Ampas Tebu+Kulit Udang $\left(\mathrm{F}_{6}\right)$ & $00,00 \mathrm{e}$ \\
Sekam Padi+Kulit Udang $\left(\mathrm{F}_{8}\right)$ & $00,00 \mathrm{e}$ \\
Kulit Udang+Dregs $\left(\mathrm{F}_{10}\right)$ & $00,00 \mathrm{e}$ \\
Sekam Padi+Kulit Udang+Dregs $\left(\mathrm{F}_{14}\right)$ & $00,00 \mathrm{e}$ \\
\hline Anga-Dangka
\end{tabular}

Angka-angka yang diikuti oleh huruf kecil yang tidak sama adalah berbeda nyata menurut uji DNMRT pada taraf 5\% setelah data ditransformasi ke dalam $\operatorname{sine}^{-1} \sqrt{\mathrm{P}}$ 


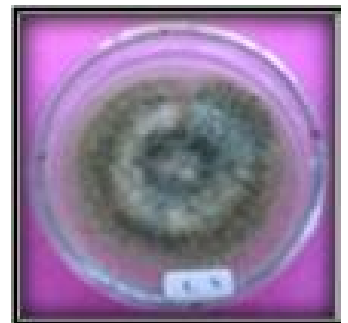

F1

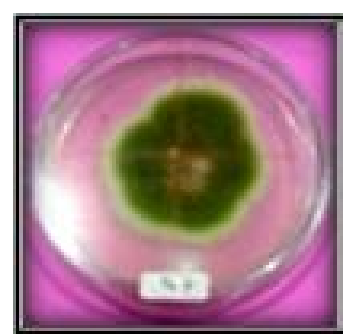

F9

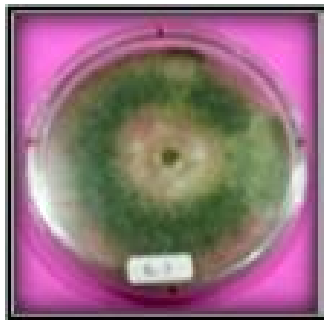

F2

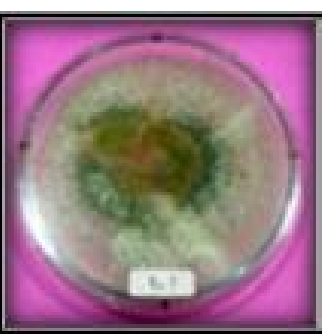

F11

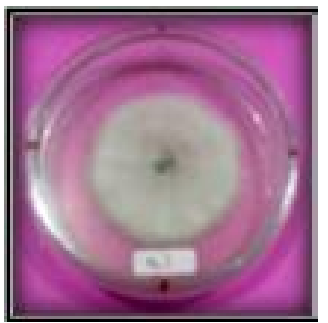

F4

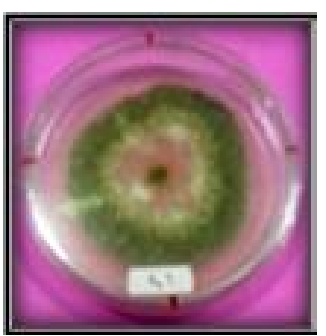

F12

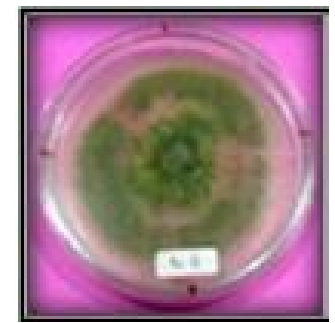

F5

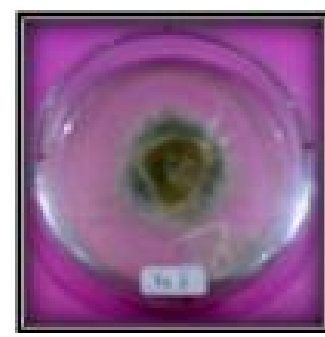

F13

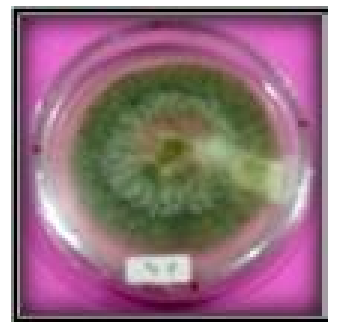

F7

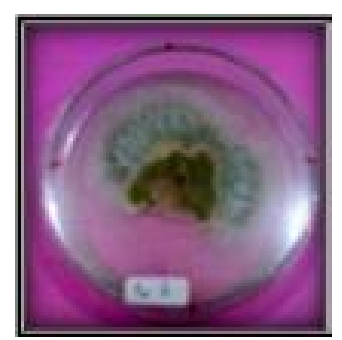

F15

Gambar 1 Diameter koloni jamur T. pseudokoningii pada masing-masing formulasi biofungisida yang mengandung bahan organik dan kombinasinya, 4 hari setelah inokulasi pada medium PDA. F1, F2, F4, F5, F7, F9, F11, F12, F13, F15.

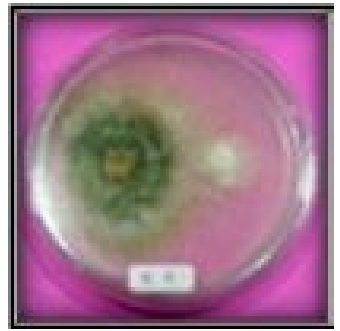

F1

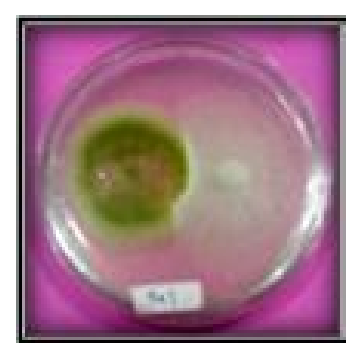

F9

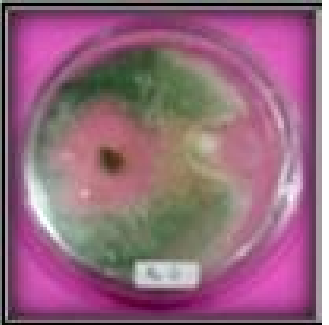

F2

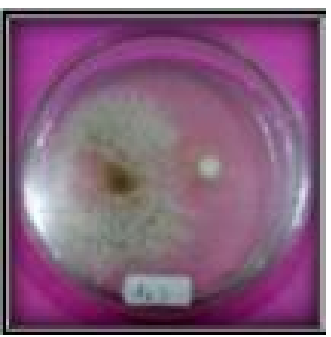

F11

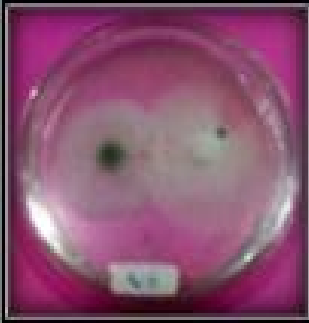

F4

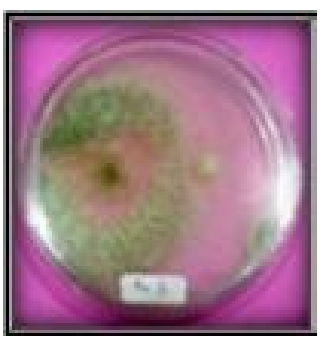

F12

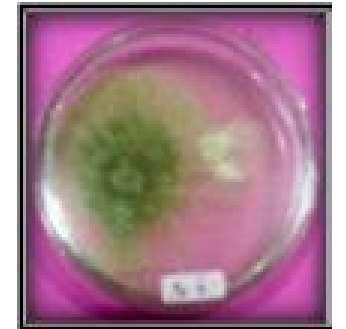

F5

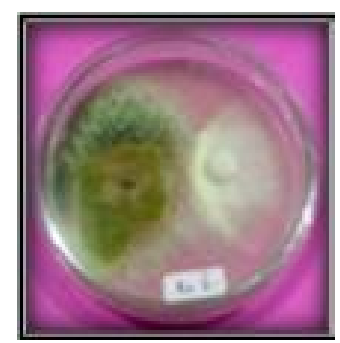

F13

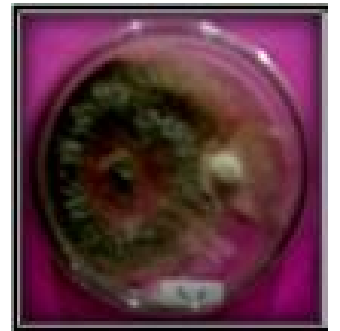

F7

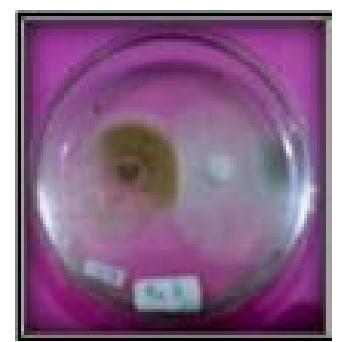

F15

Gambar 2 Daya hambat jamur T. pseudokoningii terhadap pertumbuhan jamur G. boninense pada masing-masing formulasi biofungisidayang mengandung bahan organik dan kombinasinya secara in vitro, 4 hari setelah inokulasi pada medium PDA. $\mathrm{T}=$ T. pseudokoningii dan $\mathrm{G}=$ G. boninense. F1, F2, F4, F5, F7, F9, F11, F12, F13, F15.

jamur G. boninense. Hal ini dapat pula dihubungkan dengan kecepatan pertumbuhan jamur T. pseudokoningii pada masing-masing formulasi biofungisida pada medium PDA (Tabel 1) yang selanjutnya mengakibatkan daya hambatnya menjadi lebih besar. Pendapat tersebut didukung pula oleh Octriana (2011) yang menyatakan bahwa kecepatan pertumbuhan yang tinggi dapat menentukan aktivitas mikroorganisme antagonis terhadap patogen target. Purwantisari dan Hastuti (2009) menegaskan bahwa jamur Trichoderma sp. dapat menjadi hiperparasit pada beberapa jenis jamur penyebab penyakit tanaman dan pertumbuhannya sangat cepat. Hal yang sama 
Tabel 4 Rerata jumlah spora jamur T. pseudokoningii pada formulasi biofungisida yang mengandung bahan organik dan kombinasinya $(\mathrm{CFU} / \mathrm{mL})$

\begin{tabular}{lc}
\hline \multicolumn{1}{c}{ Perlakuan } & Rerata Daya Hambat Pertumbuhan Jamur \\
& G. boninense $(\%)$ \\
\hline Sekam Padi $\left(\mathrm{F}_{2}\right)$ & $80,83 \mathrm{a}$ \\
Ampas Tebu+Sekam Padi $\left(\mathrm{F}_{5}\right)$ & $78,14 \mathrm{a}$ \\
Ampas Tebu $\left(\mathrm{F}_{1}\right)$ & $77,99 \mathrm{a}$ \\
Ampas Tebu+Dregs $\left(\mathrm{F}_{7}\right)$ & $74,17 \mathrm{a}$ \\
Ampas Tebu+Sekam Padi+Kulit Udang+Dregs $\left(\mathrm{F}_{15}\right)$ & $60,83 \mathrm{~b}$ \\
Ampas Tebu+Sekam Padi+Dregs $\left(\mathrm{F}_{12}\right)$ & $58,89 \mathrm{bc}$ \\
Ampas Tebu+Sekam Padi+Kulit Udang $\left(\mathrm{F}_{11}\right)$ & $57,63 \mathrm{bc}$ \\
Ampas Tebu+Kulit Udang+Dregs $\left(\mathrm{F}_{13}\right)$ & $51,37 \mathrm{~cd}$ \\
Sekam padi+Dregs $\left(\mathrm{F}_{9}\right)$ & $51,28 \mathrm{~cd}$ \\
Dregs $\left(\mathrm{F}_{4}\right)$ & $46,89 \mathrm{~d}$ \\
Kulit Udang $\left(\mathrm{F}_{3}\right)$ & $00,00 \mathrm{e}$ \\
Ampas Tebu+Kulit Udang $\left(\mathrm{F}_{6}\right)$ & $00,00 \mathrm{e}$ \\
Sekam Padi+Kulit Udang $\left(\mathrm{F}_{8}\right)$ & $00,00 \mathrm{e}$ \\
Kulit Udang+Dregs $\left(\mathrm{F}_{10}\right)$ & $00,00 \mathrm{e}$ \\
Sekam Padi+Kulit Udang+Dregs $\left(\mathrm{F}_{14}\right)$ & $00,00 \mathrm{e}$ \\
\hline Angka-angka yang dikuti oleh huruf & \\
\hline
\end{tabular}

Angka-angka yang diikuti oleh huruf kecil yang tidak sama adalah berbeda nyata menurut uji DNMRT pada taraf $5 \%$ setelah data ditransformasi ke dalam $\sqrt{\mathrm{y}+1 / 2}$

dikemukakan pula oleh Djafaruddin (2000) yang menjelaskan bahwa faktor penting yang menentukan aktivitas mikroorganisme antagonis dalam mengendalikan patogen adalah kecepatan pertumbuhannya yang tinggi sehingga mampu berkompetisi dengan patogen dalam hal makanan dan penguasaan ruang yang pada akhirnya dapat lebih menekan pertumbuhan jamur patogen.

Kemampuan menghasilkan senyawa antimikroba merupakan salah satu mekanisme yang juga dimiliki oleh jamur T. pseudokoningii untuk menghambat pertumbuhan jamur patogen selain kemampuannya yang cepat dalam memanfaatkan ruang dan nutrisi. Bervariasinya ketersediaan nutrisi pada masing-masing formulasi biofungisida juga dapat menyebabkan perbedaan kemampuan jamur T. pseudokoningii dalam menghasilkan senyawa antimikroba untuk menghambat pertumbuhan jamur G. boninense. Menurut Griffin (1981) kekurangan unsur-unsur esensial akan menyebabkan terganggunya proses-proses fisiologis jamur seperti terhambatnya aktivitas enzim, metabolisme karbohidrat, transfer energi, metabolisme asam nukleat dan lain-lain. Adapun enzim yang berperan dalam proses penghambatan jamur patogen adalah enzim kitinase. Menurut Habazar dan Yaherwandi (2006), Trichoderma sp. menghasilkan enzim kitinase yang mampu menghidrolisis kitin dari dinding hifa jamur patogen sehingga menyebabkan lisis. Enzim ini terdiri dari eksokitinase, endokitinase dan chitobiosidase. Besarnya daya hambat pertumbuhan jamur G. boninense oleh jamur T. pseudokoningii pada setiap bahan organik terlihat pada Gambar 2.

Gambar 2 menunjukkan perbedaan daya hambat jamur T. pseudokoningii terhadap pertumbuhan jamur G. boninense yang disebabkan karena kemampuannya yang cepat dalam menempati ruang dan nutrisi, adanya senyawa antimikroba dan enzim. Rogis et al. (2007) menegaskan bahwa kitinase merupakan enzim yang penting dalam pengendalian jamur patogen karena aktivitas enzim ini dapat menyebabkan terurainya dinding sel hifa serta perubahan komposisi sitoplasma sel jamur patogenik yang menginfeksi tanaman dan merangsang respon resistensi dari tanaman. Nugroho et al. (2003) mengemukakan bahwa Trichoderma viride yang diisolasi dari perakaran jeruk di Riau diketahui menghasikan tiga jenis kitinase, yaitu NAGse, kitobiosidase dan endokinase, bahkan enzim kitinase produksi genus Trichoderma sp. lebih efektif dari enzim kitinase yang dihasilkan oleh organisme lain, untuk menghambat berbagai jamur patogen tanaman. Trichoderma sp. juga memiliki enzim selulase yang dapat mengurai bahan organik seperti karbohidrat, terutama selulosa. 
Derajat keasaman $(\mathrm{pH})$ juga memegang peranan dalam proses pertumbuhan dan perkembangan jamur T. pseudokoningii serta berperan penting dalam proses metabolismenya untuk menghasilkan senyawa-senyawa antibiosis dan enzim-enzim yang dapat menghambat perkembangan jamur patogen $G$. boninense. Oleh karenanya, formulasi yang mengandung bahan organik: $\mathrm{F}_{1}, \mathrm{~F}_{2}, \mathrm{~F}_{5}$, dan $\mathrm{F}_{7}$ yang memiliki nilai $\mathrm{pH}$ yang rendah (asam) menunjukkan daya hambat yang lebih besar terhadap jamur G. boninense dibandingkan dengan formulasi yang mengandung bahan organik lainnya yang memiliki $\mathrm{pH}$ tinggi (basa). Waksman (1952) menyatakan bahwa Trichoderma sp. mampu tumbuh pada keasaman yang tinggi yaitu pH 2,1-2,5. Elfina dan Rianti (2004) mengemukakan pula bahwa pada $\mathrm{pH}$ tinggi yaitu $\mathrm{pH}$ di atas 8 dapat menghambat pertumbuhan dan perkembangan populasi propagul Trichoderma sp. pada kompos tandan kosong sawit. Selanjutnya dikatakan bahwa produksi biomassa optimum Trichoderma sp. terjadi pada rentang $\mathrm{pH}$ antara 4,6 dan 6,8.

Jumlah Spora Jamur T. pseudokoningii pada Formulasi Biofungisida (CFU/mL). Penggunaan beberapa bahan organik dan kombinasinya dalam formulasi biofungisida memberikan pengaruh yang nyata terhadap jumlah spora jamur T. pseudokoningii setelah dianalisis ragam. Hasil uji lanjut DNMRT pada taraf 5\% dapat dilihat pada Tabel 4.

Tabel 4 menunjukkan bahwa jumlah konidia jamur T. pseudokoningii dalam formulasi biofungisida yang mengandung bahan organik: $\mathrm{F}_{7}$ dan $\mathrm{F}_{12}$ berbeda tidak nyata sesamanya, namun berbeda nyata dengan perlakuan lainnya. Data pada Tabel 4 memperlihatkan bahwa formulasi biofungisida yang mengandung bahan organik dapat meningkatkan jumlah konidia jamur $T$. pseudokoningii adalah bahan organik dari ampas tebu dan sekam padi. Hal ini dapat disebabkan tingginya kandungan nutrisi pada kedua bahan tersebut sehingga jamur T. pseudokoningii dapat tumbuh dengan baik dan dapat memproduksi konidia yang banyak. Ampas tebu sebagian besar mengandung lignoselulosa, air $48-52 \%$, gula rata-rata 3,3\% dan serat rata-rata $47,7 \%$ (Husin 2007). Komposisi dari sekam padi terdiri dari protein kasar 3,03\%, lemak 1,18\%, serat kasar 35,68\% dan karbohidrat kasar 33,71\% (Suharno 1979 dalam Sugiarti \& Widyatama 2009). Kandungan serat dan karbohidrat yang cukup tinggi dalam suatu bahan dapat menjadi sumber nutrisi dan sumber karbon yang potensial untuk pertumbuhan jamur Trichoderma spp. atau mikroorgnisme pada umumnya (Wahyudi \& Suwahyono (1997) dengan Winarsih (2007)).

Dregs dan kulit udang dalam jumlah yang sedikit dapat pula menjadi sumber nutrisi bagi pertumbuhan dan perkembangan jamur T. pseudokoningii seperti terlihat pada Tabel 4. Hal ini karena senyawa penghambat (logam berat dan kitin) yang terkandung di dalam kedua bahan tersebut telah berkurang konsentrasinya ketika dilarutkan di dalam akuades pada saat melakukan pengujian dengan metode hitungan cawan. Elfina et al. (2007) menjelaskan bahwa setiap $1 \mathrm{Kg}$ dregs terdapat kandungan $\mathrm{N}$-total $40 \mathrm{mg}$, P-total $37 \mathrm{mg}, \mathrm{K} 4 \mathrm{mg}$, Ca $32 \mathrm{mg}, \mathrm{Mg} 48 \mathrm{mg}$, Fe 5 2,12 mg, Zn 20,14 mg, Cu 50,20 mg, Mo 3,14 mg dan Al 1,9 mg, sedangkan di dalam kulit udang terkandung protein (25-40\%), kalsium karbonat $(53,70-78,40 \%)$ dan kitin (18,70-32,20\%) Carlile dan Watkinson (1995) dalam Uruilal et al. (2012) mengemukakan bahwa faktor-faktor yang berpengaruh terhadap pertumbuhan dan perkembangan jamur antara lain nutrisi meliputi gula, polisakarida, asam-asam organik, lipid sebagai sumber karbon; nitrat, amonia, asam-asam amino, polipeptida, dan protein sebagai sumber nitrogen; hidrogen, oksigen, sulfur, fosfor, magnesium, dan potasium. Selanjutnya dikatakan bahwa unsur $\mathrm{C}, \mathrm{H}$, dan $\mathrm{O}$ adalah tiga unsur penting yang tersedia di dalam komponen organik. Fungsi utama nutrisi adalah sebagai sumber energi, bahan pembentuk sel dan aseptor elektron di dalam aksi untuk menghasilkan energi. Griffin (1981) juga menjelaskan bahwa jamur antagonis sangat membutuhkan nutrisi esensial yang meliputi karbon, hidrogen, oksigen, posfor, nitrogen, sulfur, dan kalsium dalam pertumbuhannya. Kekurangan unsur-unsur esensial akan menyebabkan terganggunya proses-proses fisiologis jamur seperti terhambatnya aktivitas enzim, metabolisme karbohidrat transfer energi, metabolisme asam nukleat, dan lain-lain.

\section{SIMPULAN}

Bahan organik dan kombinasinya dalam formulasi biofungisida berpengaruh terhadap daya hambat jamur T. pseudokoningii terhadap jamur G. boninense secara in vitro. Sekam padi, ampas tebu, ampas tebu+sekam padi 
dan ampas tebu+dregs memiliki kemampuan yang baik dalam mendukung pertumbuhan dan daya hambat jamur $T$. pseudokoningii terhadap G. boninense dibandingkan dengan bahan organik lainnya. Penggunaan kulit udang, ampas tebu+kulit udang, sekam padi+kulit udang, kulit udang+dregs dan sekam padi+kulit udang+dregs dalam formulasi biofungisida menyebabkan pertumbuhan jamur T. pseudokoningii terhambat.

\section{DAFTAR PUSTAKA}

Baker, K.F \& Cook, R.J. 1974. Biological Control of Plant Pathogens. Amerika: W.H. Freman and Company.

Budiyanto, A.K. 2010. Faktor Lingkungan yang Mempengaruhi Mikroba. http://zaifbio.wordpress.com /2010/11/08/pertumbuhan-mikroorganisme/. (7 Agustus 2012).

Djaffaruddin. 2000. Dasar-Dasar Pengendalian Penyakit Tanaman. Jakarta: Bumi Aksara.

Elfina, Y \& Rianti. 2004. Penggunaan Trichoderma harzianum untuk pengomposan limbah pertanian. Laporan Penelitian. Pekanbaru: Lembaga Penelitian Universitas Riau.

Elfina, Y.F., Puspita \& Fitridayanti, N. A. 2010. Penggunaan Trichoderma spp. lokal Riau untuk mengendalikan Ganoderma boninense Pat. pada pembibitan awal kelapa sawit. Prosiding. Pekanbaru: Badan Kerja Sama Pusat Studi Lingkungan Hidup ke-XX. 14-16 Mei.

Elfina, Y., Sampurno, Wardati \& Puspita, F. 2007. Pemanfaatan Trichoderma sp dan dregs (limbah pabrik kertas) untuk meningkatkan pertumbuhan dan hubungannya dengan serangan penyakit kelapa sawit. Laporan. Pekanbaru: Researh Grant I-MHERE Project Universitas Riau, 76 hal.

Elfina, Y., Mardinus, T., Habazar \& Bachtiar, A. 2001. Studi kemampuan isolat-isolat jamur Trichoderma spp. yang beredar di Sumatra Barat untuk pengendalian jamur patogen Sclerotium rolfsii pada bibit cabai. Prosiding. Bogor: Kongres Nasional XVI dan Seminar Ilmiah Perhimpunan Fitopatologi Indonesia, hal 167173.

Firdaus, F., Darmawan, E \& Mulyaningsih, S. 2009. Karakteristik spektra infrared (IR) kulit udang, khitin, dan khitosan yang dipengaruhi oleh proses demineralisasi, deproteinisasi, deasetilasi I dan deasetilasi II. Skripsi. Yogyakarta: Universitas Islam Indonesia (Tidak dipublikasikan).

Gendjar, I., Samson, R. A., Vermeulen, K.V.D. T., Oetari, A. \& Santoso, I. 1999. Pengenalan Kapang Tropik Umum. Jakarta: Penerbit Yayasan Obor Indonesia.

Griffin, H.D. 1981. Fungal Physiology. New York: A Wiley Interscience Publication.
Penggunaan baban organik dan kombinasinya

Habazar, T \& Yuherwandi. 2006. Pengendalian Hayati Hama dan Penyakit Tumbuhan. Padang: Andalas University Press.

Husin, A.A. 2007. Pemanfaatan limbah untuk bahan bangunan. http://www.kimpraswil.go.id /balitbang/ puskim/homepage\%20 Modul\%202003/modulc 1/ MAKALAH\%20C1_pdf. Diakses tanggal 25 Februari 2010.

Kharisma, N. 2011. Uji konsentrasi dregs terhadap Trichoderma pseudokoningii T-ks dan pengaruhnya pada Ganoderma boninense Pat. secara in vitro. Skripsi. Pekanbaru: Fakultas Pertanian Universitas Riau. (Tidak dipublikasikan).

Nugroho, T.T., Ali, M., Ginting, C., Wahyuningsih \& Dahliaty. A. 2003. Isolasi dan karakterisasi sebagian kitinase Trichoderma viride TNJ 63. Jurnal Natur Indonesia 5(2): 101-106.

Octriana, L. 2011. Potensi agen hayati dalam menghambat pertumbuhan Phytium sp. secara in vitro. Buletin Plasma Nutfah 17(2): 138-142.

Purwantisari, S \& Hastuti, R.B. 2009. Uji antagonisme jamur patogen Phytophthora infestans penyebab penyakit busuk daun dan umbi tanaman kentang dengan menggunakan Trichoderma spp. isolat lokal. Jurnal Bioma 11(1): 24-32.

Purwantisari, S., Priyatmojo, A \& Raharjo, B. 2008. Produksi biofungisida berbahan baku mikroba antagonis indigonius untuk mengendaliakan penyakit lodoh tanaman kentang di sentra- sentra pertanaman kentang di Jawa Timur. http://balitbangjateng.go.id/ kegiatan/rud/2008/8-biofungisida.pdf. Diakses tanggal 6 Desember 2011.

Rogis, A., Pameskas, T \& Mucharromah. 2007. Karakteristik dan uji efikasi senyawa bahan alami chitosan terhadap patogen pasca panen antraknosa Colletrotichum musae. Jurnal Ilmu-ilmu Pertanian Indonesia 9: 58-63.

Sugiarti, W \& Widyatama, W. 2009. Pemanfaatan kulit biji mete, bungkil jarak, sekam padi dan jerami menjadi bahan bakar briket yang ramah lingkungan. Skripsi. Semarang: Jurusan Teknik Kimia Universitas Diponegoro. (Tidak dipublikasikan).

Susanto, A., Sudharto, P.S \& Purba, R.Y. 2005. Enhancing biological control of basal stem rot disease (Ganoderma boninense) in oil palm plantations. Jurnal Mycopathologia 159(1): 153-157.

Trizelia, W. 2013. Aktivitas Antagonistik dan Karakterisasi Jamur yang Berasosiasi dengan Nematoda Bengkak Akar (Meloidogyne spp.) pada Tanah dan Akar Tanaman Tomat. http://repository.unand.ac.id/6460/1/ artikel.pdf. (20 Maret 2013).

Uruilal, C., Kalay, A.M., Kaya, E \& A. Siregar. 2012. Pemanfaatan kompos ela sagu, sekam dan dedak 
sebagai media perbanyakan agens hayati Trichoderma harzianum Rifai. Jurnal Agrologia 1(1): 21-30.

Wahyudi, P \& U. Suwahyono. 1997. Proses Produksi Biofungisida Trichoderma harzianum Bentuk Padat dengan Memanfaatkan Bahan Baku Lokal. Pusat Penelitian dan Pengembangan Teknologi Bioindustri. Badan Pengkajian dan Penerapan Teknologi.

Waksman, A.S. 1952. Soil Microbiology. Jhon. New York: Wiley and Sons.
Weller, D.M \& Cook, RJ. 1983. Suppression of take-all of wheat by seed treatments with fluorescent pseudomonand. Phytopathology 73: 463-469.

Winarsih, S \& Syafrudin. 2001. Pengaruh pemberian Trichoderma viride dan sekam padi terhadap penyakit rebah kecambah di persemaian cabai. Jurnal Ilmu-ilmu Pertanian Indonesia 3(1): 49-55. 